短—報

\section{魚類の低酸素ストレス耐性に及ぼす 飼料アスコルビン酸投与の効果}

石橋泰典，家戸敬太郎，池田静徳， 村田 悠, 那須敏朗, 㠇并英水 (1992 年 3 月 18 日受付)

Effect of Dietary Ascorbic Acid on the Tolerance for Low Oxygen Stress in Fish

Yasunori Ishibashi,*1,2 Keitaro Kato,*1 Shizunori Ikeda, ${ }^{* 1}$ Osamu Murata,*1

Toshiro Nasu, ${ }^{* 1}$ and Hidemi Kumai*1

養殖魚は常に多かれ少なかれ，環境水の溶存酸素分王， 本温，塩分などの变動をストレスとして受けている。 しかし、これらのストレス反応にビタミンの久そあるい は投与がどの上うに影響するかについては，まだ任とん ど研究されていない。そこで本報では，まず環境水の溶 存酸素量 (DO) の低下に対する魚類の耐性に及ぽすフス コルビン酸 (AsA) 投与の効果を調べた。

試料魚としては，平均体重約 $100 \mathrm{~g}$ のンダイ $O p$ legnathus fasciatus (I) およびイシガキダイ Oplegnathus punctatus (II) を, 北洋ミールをタンパク質源とし

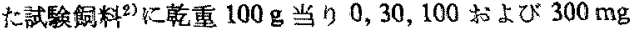
のAsAをそれぞれ添加した各区餇料》で，Iは120日 間，II は70 日間飼育したるのを用いた。これらの試料 魯を低酸素ストレス苗荷実験に供したときの平均体重沶 上び各飼料区の魚の肝臓 AsA 濃度は Table 1 に示した とおりである。いずれの魚種炕いてす，AsA 無添加区 に拈りる欠之症の発現はみられず，李た健康度の指標と して測定した血液のーマトクリット值，赤血球数执よび ヘモグロビン濃度には各飼料区間に有意差は認められな かった。なお、肝葴 AsA 濃度の湘定には DNPH-HPLC 法早用いた。

低酸素ストレスの負荷は，500l 容円形水槽を 4 区画 に代切った負荷槽に，別の調節槽で空素ガス通気量を調 節して任意のDOとした水温 $20.0 \pm 0.1^{\circ} \mathrm{C}$ の海水を連 続的に注水しながら，次の上うに行った。すなわり，I在 用いた実験では，DO を約 4 時間加て $4.6 \mathrm{~m} / / \mathrm{l}$ から
$0.8 \mathrm{ml} / l$ 付近に变で下げ，その DOに 4 時間保った後。 徐々にDOを上げ約 3 時間がて正常に戻した。この ストレス負荷条件は，予備実験の結果，供試魚の“半数 横転時閐 (min)”を指標として各飼料区の魚の低酸素ス トレス耐性を比較するのに好適な条件として設定したす のである。一方，IIを用いた铁験では，供試魚の“へい 死率 (\%)”を指標しして比較するために，DOを約 4 時 間かけて $4.8 \mathrm{ml} / l$ から $0.8 \mathrm{ml} / l$ 付近にまで下げ，その DOに2 時間保った後,さらに 1 時間加て $0.6 \mathrm{~m} l / l$ に 屯で下げ，その状熊を 1 時間持続し，それからDOを徐 々に回復さぜた。

実駼結果をうめて Table 1 に示した。I 用いた雪 験に括ける “LDT 5. 供試魚の $50 \%$ が横転するのに要した時間, $n=12$ ) は, AsA $0 \mathrm{mg}$ 区が最も早くて 19 分であったのに対し. AsA $30 \mathrm{mg}$ 区标よび $100 \mathrm{mg}$ 区ではいずれも 49 分，さ らにAsA $300 \mathrm{mg}$ 区では73 分を要した。1Iを用いた帮 験では, “FDT" (DO が $0.8 \mathrm{ml} / \mathrm{l}$ にで低下してから最 初の人い死魚分涊められるのに要した時間， $n=10$ )は. AsA $0 \mathrm{mg}$ 区では 11 分, AsA $30 \mathrm{mg}$ 区では 18 分であ ったが，AsA $100 \mathrm{mg}$ 区扎よび $300 \mathrm{mg}$ 区では 200 分以 上であった。また DO $0.8 \mathrm{~m} / \mathrm{l}$ 以下に 4 時間保った ときの “へい死率” $(n=10)$ は, AsA $0 \mathrm{mg}$ 区では $50 \%$ であったが,AsA $30 \mathrm{mg}$ 区特よび $100 \mathrm{mg}$ 区ではいずれ 斥 $20 \%$ ，さらに AsA $300 \mathrm{mg}$ 区では $10 \%$ に過ぎなか sto

以上の結果から，環境水の DO 低下をストレッサーと した埸合の、いわゆる低酸素ストレスに対する焦類の耐

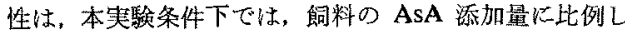
て增大することがわが的た。AsA の作用機構について

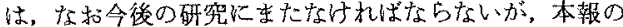
結果は, 魚類におけるビタミンのの重要な生理作用のひ とつとして注目されてよいと考えられる。

\section{文献}

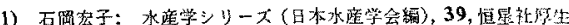
激, 策京, 1982, pp. 52-69.

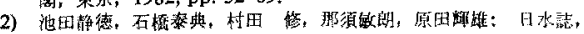
54, 151-154 (1988).

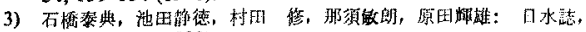
$58,267-270(1992)$.

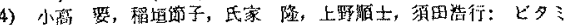
, 59, 451-455 (1985).

Table 1. Effect of dietary ascorbic acid levels on the tolerance of fish to the stress arose from water oxygen reduction

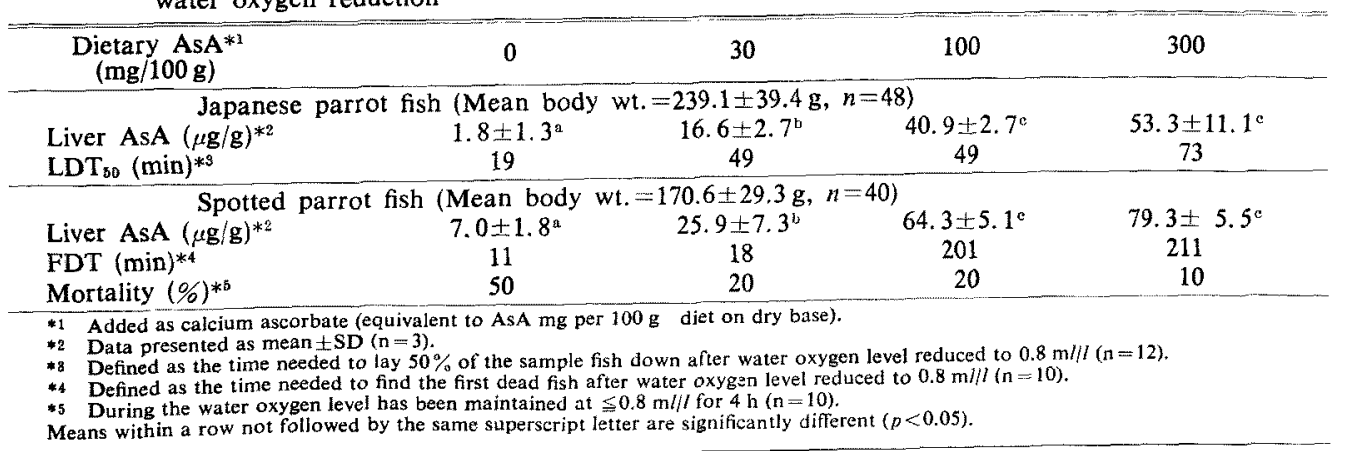

*1 近幾大学水研究所 (Fisheries Laboratory, Kinki University, Shirahama, Wakayama 649-22, Japan)

*2 現所属: 近畿大学膘学部 (Faculty of Agriculture, Kinki Univers!ty, Nakamachi, Nara 631, Japan).

Nippon Suisan Gakkaishi : Formerly Bull. Japan. Soc. Sci. Fish. 